\title{
Vygostky’nin Sosyo- Kültürel ve Bilişsel Gelişim Teorisi Bağlamında Türkçe Öğretiminin Değerlendirilmesi ${ }^{1}$
}

\section{Evaluation of Teaching Turkish in the Context of Vygotsky's Theory of Socio- Cultural and Cognitive Development}

\section{Dilek ÜNVEREN KAPANADZE*}

\author{
Süleyman Demirel Üniversitesi, Eğitim Fakültesi, Türkçe ve Sosyal Bilimler Eğitimi Bölümü, \\ dilekkapanadze@sdu.edu.tr
}

ORCID Numarası I ORCID Number: 0000-0003-3415-9274

ÖZ

Vygotsky'nin düşünceleri ve görüşleri etrafında oluşturulmuş olan sosyo-kültürel yapılandırmacıllı̆ın temel önermesi, bilişin gelişmesinde sosyal etkileşimin önemli bir yerinin olduğudur. Bu yaklaşımda, öğrenmenin meydana gelmesinde zengin birtakım yaşantılar sağlayacak olan sosyal çevreye olan gereksinim, deneyimli akran ve öğretmenlerin varlığ 1 gibi durumlar bilişsel fonksiyonların gelişmesinde önemli bir yere sahiptir. Bu bağlamda çalışmanın temel amacı Türkçe öğretiminin Vygotsky'nin 'Bilişsel Gelişim Kuramı'nın önemli kavramlarından olan yakınsal gelişim alanı açısından değerlendirilmesi ve kavramın Türkçe öğretimine ne şekilde yansıdığının araştırılmasıdır. Bu inceleme yapılırken Vygotsky’nin görüşleri etrafında oluşmuş yaklaşım ve stratejilerle diğer bilişsel gelişim kuramları da göz önünde bulundurulmuştur. Araştırmada nitel bir araştırma yöntemi olan doküman inceleme kullanılmış, ortaokul Türkçe Ders Kitapları (5-8) ve Türkçe Öğretim Programı ele alınmıştır. Sonuç olarak, yapılan araştırmada elde edilen bulgular ışığında; yakınsal gelişim alanının Türkçe öğretiminde yer bulduğu, gerek öğretim programının yaklaşımında gerekse öğretim materyallerinde yakınsal gelişim alanını destekleyen, bu olguyla ilişkili yapıların olduğu tespit edilmiştir.

Anahtar Sözcükler: Sosyo-kültürel Gelişim, Vygotsky, Bilişsel Gelişim, Türkçe Öğretimi

\section{ABSTRACT}

The main proposition of socio-cultural constructivism, developed around Vygotsky's ideas and views is that social interaction is an important part of cognitive development. In this approach, the necessity of social environment which will provide a rich experience in the learning process, the presence of experienced peers and teachers have an important place in the development of cognitive functions. In this context, the main aim of the study is to evaluate Turkish language teaching in terms of zone of proximal development, which is one of the important concepts Vygotsky's Cognitive Development Theory and to investigate how this concept was reflected in Turkish teaching. While doing analysis, approaches and strategies around Vygotsky's views and other cognitive development theories were taken into consideration. In the study, documentary analysis, a qualitative research method, was used and secondary school Turkish textbooks (5-8) and Turkish curriculum were analyzed. In the light of the findings of the research, it has been concluded that there are structures related to the zone of proximal development and that support it, in the approach of teaching program and in the teaching materials which were reviewed.

Key Words: Socio-cultural Develeopment, Vygotsky, Cognitive Development, Turkish Language Teaching

\footnotetext{
${ }^{1}$ Bu araştırma, 18-20 Nisan 2019 tarihlerinde Alanya'da düzenlenen "6.Uluslararası Eğitim Bilimleri Sempozuyumu”nda sözlü bildiri olarak sunulup özet olarak basılan çalışmanın genişletilerek makale haline dönüştürülmesiyle oluşturulmuştur.
} 


\section{Giriş}

\subsection{Biliş ve Bilişsel Gelişim}

Biliş kavramı, içsel zihinsel süreçleri ifade etmektedir. Nitekim zihnin içindeki birçok olguyu kapsayan geniş bir terim olan biliş; dikkat, algı, bellek, okuma ve yazma, problem çözme vb. unsurları da ifade etmekte ve kapsamaktadır (Bayhan ve Artan, 2007).

Bilişsel gelişim araştırmaları genel olarak çocukların düşünme süreçlerinin zaman içinde nasıl değiştiğini inceleyen bir alandır. 1950-1960'l1 yıllarda bilişsel psikolojinin ve bilişsel gelişim ile ortaya çıkmış olan 'biliş çalışmaları' ve 'biliş’; karar alma gibi bilinçli olarak ve çaba ile gerçekleştirilen süreçlerin yanı sıra daha önceden bilinen sözcük, yüz ve nesneleri hatırlama gibi bilinçli olarak değil de otomatik olarak gerçekleştirilen süreçleri de kapsamaktadır (Kaya ve diğerleri, 2012).

\subsection{Bilişsel Psikolojinin Temel Olguları}

Söz konusu psikoloji alanının öğrenmeye ait temel olgu ve varsayımları genel itibariyle şu şekilde özetlenebilir:

Bilginin insan zihninde nasıl ve ne şekilde işlendiğine dair yapılan açıklamalar bilişsel psikolojide çocukların; bilgiyi kazanma, değiştirme ve kullanma gibi bir dizi süreci içeren 'bilgiyi işleme kuramının' ortaya çıkmasını sağlamıştır (Kaya ve diğerleri, 2012). Bu kuramda; insanların kolay öğrenmelerinin altında yatan etmenlerden biri, yeni bilgiyi önceki öğrenmeleriyle birlikte örgütlemeleri ve kişilerin birbirinden bağımsız bilgi ya da bilgi parçalarını ilişkilendirerek bir araya getirmek kaydıyla bir kurgu çatısı altında toplamalarıyla daha kolay öğrenmelerin gerçekleştiği ifade edilir. Bunlarla beraber yapılandırmacı kuramlar olarak bilinen ve öğrenen bireyin bilgiyi yapılandırmasına ilişkin unsurlar da bilişsel öğrenme kuramlarının temelinde yer alır. Kişilerin kendi öğrenme süreçlerine aktif bir şekilde katılım sağladığını ifade eden bilişsel psikologlar; insanın bilgileri dış çevreden var olduğu şekliyle almadıklarını, bunun yerine kendi ögrenme süreçlerinde etkin bir rol oynadıklarını belirtirler. Her bir bireyin/öğrencinin kendine özgü birtakım yaşanmışlıkları, farklılıkları ve kültürel özellikleri vardır. Bir öğrenme-öğretme ortamındaki öğrencilerin sürecin sonunda farklı şeyler öğrenmelerinin temel nedeni de işte bilgiye farklı önceki öğrenmeler ve farklı duyuş ve düşünüş tarzları ile yaklaşmış olmalarıdır. Hafiza, kayıt, kodlama, geri çağırma gibi ifadelerin en temel terimlerini oluşturduğu bilişsel psikolojinin en önemli kuramcıları arasında ise Jean Piaget ve Lev Vygotsky gösterilmektedir.

\subsection{Vygotsky'nin Bilişsel Gelişim Kuramının Ana Hatları}

Çocukların gelişimi başta olmak üzere öğrenme ve öğretim konusunda da çalışmalar yapmış olan Vygotsky; Piaget'den farklı olarak gelişimi çocukların kişisel süreçleri olmaktan ziyade toplumdaki yetişkinlerin bilişsel gelişimleri istendik ve sistematik bir şekilde sağladıkları görüşündedir (Kaya ve diğerleri, 2012). Dolayısıyla yetişkinlerin çocukların gelişimlerinde önemli katkıları vardır. Yetişkinler, çocuklara, anlamlı ve onları bilişsel açıdan güçlendirecek birtakım eylemler ve etkinlikler sunarlar ve bunları başarmaları konusunda onlara yardım ederler. Vygotsky'nin ortaya koyduğu sosyo-kültürel kuram, konuşma dili ile birlikte bilişsel gelişimi sağlama konusunda toplum ve kültüre vurgu yapar. Bunun dışında Vygotsky'nin bilişsel gelişim kuramının ana hatları şu şekilde ifade edilebilir:

- Dil, sembol, edebiyat, matematik, sanat vb. araçlarla yetişkinler, formal ve informal iletişimler sonucunda anlamları ve değerleri çocuklara aktarırlar.

- Çocukluğun ilk dönemleri düşünme ve dil arasında bağımlı bir ilişki vardır.

- Karmaşık zihinsel süreçlerin başlangıcında sosyal etkileşimler vardır, bir başka ifadeyle zihinsel süreçler sosyal etkileşimlerle başlar. Bu zihinsel süreçlerde gelişim sadece yetişkinlerle değil, akran gruplarıyla girdikleri etkileşimler sayesinde de gerçekleşebilir.

- Çocukların içinde bulundukları durumdan daha ileri ya da daha başarılı kimselerin yardımı, onların zor amaçlara, hedeflere ulaşmalarını sağlar.

- İşlerin başarılması noktasında çocukların karşılarına çıkan zorlamalar, en üst düzeyde bilişsel gelişimin ortaya çıkmasına büyük katkı sağlar (yakınsal gelişim alanı). 
- Oyun kavramı Vygotsky'nin kuramında önemli bir yer tutar. Şüphe yok ki oyun; bir zaman kaybı değildir; aksine çocuğun yetişkin dünyasına katılımını sağlayan egzersizler bütünüdür (Driscoll, 2012; Kaya, 2012; Şahin, 2016; Ormrod, 2018).

Vygotsky'nin kuramı genel olarak incelendiğinde Piaget gibi yaşa bağlı bir dönemlendirme yapmadığı farklı bir model ortaya koyduğu görülür. Onun bilişsel gelişimin temeline koyduğu kavramlar yukarıda ifade edilenlerle birlikte başlıklar halinde şunlardır:

- Sosyo-kültürel model

- Yakınsal Gelişim Alanı (Zone of Proximal Development)

- İş birlikli Öğrenme

- Yapı İskelesi

Çalışmanın Türkçe öğretiminde yakınsal gelişim alanının varlığı olması nedeniyle temelde yakınsal gelişim alanı ele alınmış, Vygotsky'nin ortaya koyduğu modelde yer alan diğer kavramlara, çalışmanın konusu ile ilgili oldukları kadar yer verilmiştir.

\subsection{Yakınsal Gelişim Alanı ve İskelet Kurma}

İnsanların ne şekilde öğrendiği üzerinde durmuş olan Vygostky, öğrenen bireylerin anlamları nasıl yapılandırdığını adeta bir keşif olarak ortaya koymuştur. Onun ortaya koyduğu iskelet kurma/ yapı iskelesi/destek olma (scaffolding) kavramı, birçok eğitimci tarafından çocukların öğrenme ve gelişimlerine rehberlik etmede yetişkinlerin ve daha bilgili akranların rolünü açıklamak için kullanılagelmiştir (Daniels, 2001; Stone, 1998; Hammond, 2002; Krause, Bochner \& Duchesne, 2003). Geniş bağlamda, iskelet kurma, çocuk ve gençlerin öğrenme ve gelişimleri adına bir tür destek olarak yorumlanır (Rasmussen, 2001). Bu terim, öğretmen, diğer yetişkin ve akranların, öğrencilerin öğrenmesi için gerekli olan araçları sağlama yolunu betimlemek için şemsiye bir metafor olarak kullanılabilir (Jacobs, 2001). Yapı iskelesi kavramına ilişkin birçok tanım bulunmaktadır. Yetişkinlerin bir öğretim süreci boyunca çocuğun mevcut performasına uyacak şekilde ayarladıkları değişen kalitedeki destek olarak ifade eder (Berk, 2002).Ayrıca, iskelet kurmayı; gösterip yaptırma, bir görevi daha küçük parçalara bölme, yönergeler sunma, ilgiyi ve dikkati canlı tutma, örnekler verme ve soru sorma gibi değişik biçimlerdeki yetişkin desteği olarak da açıklayan çalışmalar vardır (McDevitt \& Ormrod, 2002). İçeriği daha yönetilebilir, halledilebilir parçalara ayırmak iskelet kurmanın en yaygın özelliği olarak görünmektedir (Berk, 2002; Eggen \&Kauchak, 1999; Krause et al, 2003). Vygotsky (1978), yap1 iskelesini, öğrenenlerin gerçekleştiremedikleri herhangi bir işi yetişkinlerin ya da akranlarının rehberliği ile tamamlayabilmeleri, onların desteği ile iskelet kurabilmeleri olarak açılar. İskelet kurma, öğretmenlerin öğrencilere bilinenden bilinmeye doğru liderlik etme yoludur. Bilgiyi küçük parçalara bölme, sonrasında yapılandırmaya doğru önderlik etme ve genişletme, iskelet kurma biçimleridir (Benson, 1997).Vygotsky, iskelet kurma terimini, işlevsel olarak Yakınsal Gelişim Alanı ile kavramsallaştırmıştır. Yakınsal gelişim alanı, yetişkinlerin gözetimi altında ya da daha iyi kapasiteye sahip akranlar ile işbirliği yoluyla geliştirilen problem çözme tekniğidir (Vygotsky, 1978) Yap1 iskeleleri ile, bir uzman, iyi bilgilendirilmiş bir kimse ya da akran öğrencilere hedeflerine ve amaçlarına ulaşmada yardımcı olabilir, önceden öğrenmiş oldukları becerileri, iş ve yaklaşımları kullanmalarını sağlayarak bu becerilerde ustalık düzeyinde kendilerini geliştirmelerini sağlayabilir (Winne \& Hadwin, 2001). Böylelikle yardımcı olan kişi, destekleyici rehberlik yoluyla öğrenmenin bir parçası olur. Öğretmen ya da uzman, iskelet kurma yoluyla, öğrenenlerde yaratıcıllı̆ı ortaya çıkarır, iskelet kurmanın en önemli yönü de budur (Vygotsky, 1978).

Yeterli düzeyde iskelet kurma yönergeleri yoluyla aktif öğrenme süreçleri yaratılarak karmaşık olgular, zor kavramlar ve becerilerle baş edebilir. (Crandall, 2002). Vygotsky tarafından açıklanan sosyo-kültürel eğitim kuramı, bireyin akademik başarısına vurgu yaparken, yapılan araştırmalarla daha da derine inilerek öğretimde yardımcı süreçler olarak ortaya konmuştur. İskelet kurmanın benzersiz anlayışı, bir uzmanın ya da bilgili bir kişinin öğrenenlere sadece görevleri yerine getirmelerinde yardımcı olmakla kalmayıp görevlere yönelik kritik konuları vurgulayıp soruların yanı sıra ipuçları sunma yoluyla öğrenenlerin yansıtıcı düşünmelerini destekleyerek modelleme biçiminde bu işlemleri sürdürebilmelerini de sağlar (Wood vd., 1976). 
'İskele' kavramı 'Yakınsal Gelişim Alanı' ile yakından ilgilidir ve Vygotsky'nin 'Yakınsal Gelişim Alanı'nı eğitim ortamlarına uygulayan diğer teorisyenler tarafından geliştirilmiştir. İskele kurma, bir öğretmenin ya da daha yetenekli bir akranın öğrencinin yakınsal gelişim alanında gerektiği şekilde öğrenciye yardım ettiği ve tıpkı inşaat sırasında bir iskelenin binadan çıkarılması gibi, yardımın artık gereksiz olduğu noktada azaltılıp sonlandırıldığı bir süreçtir. Başka bir deyişle, çocuğun öğrenme sürecinde, odaklanmış sorular ve olumlu etkileşimler yoluyla rehberlik edilmesidir (Balaban, 1995).

Vygotsky'ye göre sosyal yaşantılar, düşünmeyi ve dünyayı yorumlama yollarını şekillendirmektedir. Bireysel biliş, toplumsal bağlamda kendini göstermekte, grup; üst düzey zihinsel öğrenme için bir öğrenme yolu olarak değerlendirilmektedir (Yurdakul, 2005). Vygotsky'nin düşünceleri ve görüşleri etrafında oluşturulmuş olan sosyo-kültürel yapılandırmacılığın temel önermesi, bilişin gelişmesinde sosyal etkileşimin önemli bir yerinin olduğudur. Bu yaklaşımda, öğrenmenin meydana gelmesinde zengin birtakım yaşantılar sağlayacak olan sosyal çevreye olan gereksinim, deneyimli akran ve öğretmenlerin varlığ1 gibi durumlar bilişsel fonksiyonların gelişmesinde önemli bir yere sahiptir. Bir diğer ifadeyle sosyo-kültürel yapılandırmacılık, bilişin sosyal kaynağını ve anlamı yapılandırmada kültürel olarak belirlenmiş bağlamını incelemektedir (Duman, 2004). Bu anlamda Vygotsky bilişsel gelişim sürecinde daha çok toplumsal köken ve bu türden dinamikler üzerine vurgu yapar. Bu bağlam içinde birey bilişsel süreçte problemleri çözme becerilerinde yardım almadan ve yardım alarak çözebileceği bir gelişim alanının içerisindedir ve bu alana da yakınsal gelişim alanı adı verilir.

Kaynaklarda 'gelişmeye açık olan alan', 'yakınsak gelişim alanı' şeklinde de ifade edilen yakınsal gelişim alanı; öğrencinin/çocuğun tek başına öğrenebileceği ya da var olan gelişim düzeyiyle, bir başkasının yardımıyla ulaşabileceği potansiyel gelişim düzeyi arasındaki farkı ifade etmektedir ve öğrenme de bu iki düzey arasında, tam da bu aşamada başlamaktadır (Kaya vd., 2010). Sosyal çevrenin etkisiyle oluşan bu alan gelişmeye açıktır. Haliyle birey/çocuk bir yetişkinle çalıştığında çocuktaki/bireydeki öğrenme daha fazla olacaktır.

Vygotsky'ye göre öğrenme ve gelişim süreçleri bir öğretici ya da aktarıcı topluluğu içerisinde gerçekleşir. Bu nedenle de kişi, tek başına olduğu durumlarda potansiyeli sınırlanacağından, çok az şey öğrenebilmektedir. Kişi ancak sosyal bir çevre içerisinde potansiyeline ulaşır ve dolayısıyla da bilişsel gelişim gerçekleşir. Vygotsky; bireylerin doğuştan getirdikleri potansiyellerinin bilişsel gelişimi başlattığını düşünen Piaget'nin aksine, öğretmen, anne-baba, diğer yetişkin ve akranların gelişimi tetikleyen unsurlar olduğunu savunur. Doğumundan itibaren bir çevrenin içinde tutulan birey onun tarafından şekillendirilerek çevrenin ortak biliş düzeyi, düşünme biçimi ve yolları da bireye aktarılır. Çocuk içinde yetiştiği toplumun sosyo-kültürel olgularına hâkim olan, ondan daha bilgili ve yetenekli akran ve yetişkinleri içinde gelişim ve öğrenme sürecini devam ettirir. Bu noktada, Vygotsky'nin bilişsel gelişim kuramının temelinde yatan çevre vurgusu yakınsal gelişim alanı kavramı içinde açık bir şekilde görünmektedir (Yıldırım, 2016)

Yakınsal gelişim alanı, bir öğrencinin uygun eğitim-öğretim koşulları kendisine sağlandığında ulaşabileceği muhtemel öğrenme miktarını temsilini ifade eder (Schunk, 2014). Temel olarak öğretmen ve öğrencilerin kültürel birtakım araçları paylaşmaları ve bu araçların öğrenci tarafından içselleştirilmesi durumunda bilişsel değişimin sağlanacağ 1 vurgusu ile ifade edilebilir. Öğrenmenin gelişmenin ötesinde olduğunu ifade eden Vygostky’ye göre, bireyler arasında meydana gelen sosyal etkileşimlerdeki öğrenmeler, yakınsal gelişim alanında oluşur ve başka bireylerle etkileşim halindeyken öğrenilen bilgiler özümsenir, bu öğrenilenler yeni gelişimsel bilgi olur (Hamamcı ve Hamamc1, 2015). Bu anlamda Vygostky, kişinin çevre ile ortaya koyduğu etkileşimin öğrenmede başarı sağlamaya katkı sunacağını belirtir. Kişinin öğrenme durumuna getirmiş olduğu deneyimlerin, sonucu çok büyük ölçüde etkileyeceğini ifade eder.

\subsection{Türkçe Öğretimi ve Yakınsal Gelişim Alanı}

Türkçe öğretiminde yakınsal gelişim alanı, özellikle öğrencileri işe koşmak suretiyle öğrenmeye teşvik etme bağlamında verilecek görevler için önem arz etmektedir. Grupların/takımların oluşturulmasında ve temel hedefleri içerisinde yer alan iş birliği içinde çalışabilen, hayat boyu öğrenen, özerklik kazanmış, problem çözebilme yetisini elde etmiş bireylerin yetiştirilmesinde yakınsal gelişim 
alanının önemi yadsınamaz. Zira Vygotsky'nin kuramında, karmaşık iç zihinsel süreçlerin ilk önce sosyal süreçler olarak başlayıp daha sonra ne şekilde özerk hale geldikleri betimlenir.

Türkçe dersi öğrenme ve öğretme ortamlarında akranlar arası tartışmaların yapılmasının sonucunda sosyal etkileşimlerin olacağ tahmin edilebilir bir durumdur. Bu bağlamda öğrencilerin tartışma sürecini içselleştirmeleri sonucunda probleme farklı bakış açılarıyla bakabilme becerisi kazanmaları da beklenen bir durumdur. Bu yolla, öğrencilerin kişiler arası etkileşim ve iletişim becerileri gelişebilir, birbirlerine akademik yaklaşımlar konusunda rol-model olabilirler. Akranlar arasında kendilerini başarılı kılmaları haliyle bir duyuşsal önerme olarak özgüven kazanmalarına yardımcı olur. Ayrıca bu türden toplumsal ihtiyaçların karşılanması öğrenme etkinliklerine katılımları konusunda motive edici olabilir.

$\mathrm{Bu}$ anlamda Türkçe ders ortamlarında sosyal yapılandırmacı yaklaşımla beraber yakınsal gelişim alanının temel önermelerinin merkeze alındığı bir öğrenme-öğretme ortamının, başta sosyal beceriler olmak üzere karmaşık zihinsel süreçlerin analitik hale getirilmesinde fayda sağlayacağı ortadadır.

Bu bağlamda çalışmanın temel amacı bilişsel gelişim kuramlarından Vygotsky'nin bilişsel gelişim kuramının önemli kavramlarından olan yakınsal gelişim alanı çerçevesinde Türkçe öğretimini değerlendirmek ve bu alan önermelerinin Türkçe öğretimine ne şekilde yansıdığını araştırmaktır. Bu inceleme yapılırken Vygotsky'nin görüşleri etrafında oluşmuş yaklaşım ve stratejilerle diğer bilişsel gelişim kuramları da göz önünde bulundurulmuştur.

\section{Yöntem}

\subsection{Araştırmanın Modeli}

$\mathrm{Bu}$ araştırmada Vygotsky'nin bilişsel gelişim kuramında ortaya koyduğu önemli kavramlardan yakınsal gelişim alanının Türkçe öğretimindeki varlığını ve yerini tespit etmek amaçlandığından yöntem olarak nitel araştırma yöntemlerinden doküman analizi kullanılmıştır. Doküman incelemesi, araştırılması hedeflenen olgu veya olgular hakkında bilgi içeren yazılı materyallerin analizini kapsar. Nitel araştırmada doküman incelemesi tek başına bir veri toplama yöntemi olabileceği gibi diğer veri toplama yöntemleri ile birlikte de kullanılabilir (Yıldırım ve Şimşek, 2005).

\subsection{Verilerin Toplanması ve Analizi}

Araştırmada veri toplama araçlarını ortaokul (5-8. sınıf) Türkçe Ders Kitapları ve Türkçe Öğretim Programı oluşturmaktadır. Türkçe ders kitaplarının organizasyon şemasını teşkil eden hazırlık, dinleme, okuma, konuşma, yazma, öğrenelim, sonraki metnin işlenişine hazırlık, etkinlik ve tema değerlendirme soruları ve ifade edilen bu olguların yer aldığı bölümlere dair yönergeler incelenmiştir. Bu inceleme yapılırken ders kitabında yer alan metinlerin içeriğine girilmemiştir. Veriler, doküman incelemesi yoluyla toplanmıştır. Doküman incelemesi, araştırılacak konular hakkında bilgi içeren yazılı materyallerin analizini kapsayan sistemli incelenmedir. Başarılı bir doküman incelemesinin temel koşulu, konuya ilişkin belgelerin bulunması, incelenmesi ve belli durum ya da görüşleri ortaya çıkartacak bir senteze varılabilmesi için gerekli düzenlemelerin yapılabilmesidir (Karasar, 2007; Yıldırım ve Şimşek, 2006).

Çalışmanın geçerliği ve güvenilirliği aşamasında literatür taramasından sonra Türkçe ders kitaplarından (5-8) Vygotsky'nin bilişsel gelişim kuramı ve yakınsal gelişim alanı ile ilgili yapılar tespit edilmiş; ortaya çıkarılan verilerin güvenirliği ve geçerliği adına incelenen dokümanlardan elde edilen bulgular öğrenme ve gelişim psikolojisi alanında uzman iki kişi ve iki Türkçe öğretmeniyle beraber değerlendirilmiş, bulgular birbirleriyle karşılaştırılmış ve görüş birliği ve ayrılığı şeklinde yeniden tasnif edilmiştir. Görüş birliği/ (Görüş birliği+ Görüş ayrılığ x 100 formülü (Miles ve Huberman, 1994) kullanılarak değerlendiriciler arasındaki güvenirliğe bakılmış, bu bağlamda araştırmanın güvenirliliği $\% 90$ olarak hesaplanmıştır. Veriler tablolar haline sunularak betimsel analiz yoluyla aktarılmıştır.

\section{Bulgular}

\section{1. (5-8. Sınıf) Türkçe Ders Kitaplarına Ait Bulgular:}

Doküman incelemesi yöntemiyle ele alınan bu çalışmada (5-8) Türkçe ders kitapları incelenmiş, yapılan incelemede Vygotsky'nin Yakınsal Gelişim Alanını ifade eden yapı taşları sınıf, tema ve ilgili ifade olarak aşağıdaki tabloda betimlenmiştir. Daha sonra elde edilen bulguların yorumlanması yoluna gidilmişstir. 
Tablo 1.

5-8 Türkçe Ders Kitaplarına Ait Bulgular

\section{SINIF TEMA \\ YAKINSAL GELIŞíM ALANI}

Aileniz ya da çevrenizdeki yetişkinlerden çocukluklarında

$5 \quad$ Çocuk Dünyas oynadıkları bir oyunu öğreniniz

Çocukluk konulu bir şiir ezberleyiniz. Öğretmeninizin belirlediği bir zamanda şiirinizi vurgu, durak ve tonlamaya

Çocuk Dünyası dikkat ederek fon müziği eşliğinde okuyunuz. Gerektiğinde

5 öğretmeninizden örnek bir okuma isteyebilirsiniz ya da farklı kaynaklardan şiirin okunuşunu dinleyebilirsiniz.

Çevremizdeki canlılara nasıl davranmalıyız?' sorusundan

$5 \quad$ Çocuk Dünyası yola çıkarak öğretmeninizin rehberliğinde bir konuşma yapinız

Ailenizdeki ya da çevrenizdeki yetişkinlerden sevdiğini bir

$5 \quad$ Bilim ve Teknoloji yemeğin yapılışını öğrenerek derse geliniz.

\begin{tabular}{|c|c|c|}
\hline 6 & Çocuk Dünyası & $\begin{array}{l}\text { Sonraki metnin işlenişinin 'Okuma' bölümünde } \\
\text { kullanılmak üzere öğretmeninizden, dizüstü bir bilgisayar } \\
\text { hazırlamasını isteyiniz. Öğretmeninize ayrıca, 'Hayat Bayram } \\
\text { Olsa' şarkısının CD ya da USB bellek aracılığıyla sınıfa } \\
\text { getirmesini isteyiniz. }\end{array}$ \\
\hline 6 & Çocuk Dünyası & $\begin{array}{l}\text { Sonraki metnin işlenişinin 'Yazma' bölümünde } \\
\text { gerçekleştirmek üzere öğretmeninizden, ' 'birlik ve } \\
\text { beraberliğin önemi'” konulu bir konuşma hazırlığı yapmasın1 } \\
\text { isteyiniz. }\end{array}$ \\
\hline 6 & Birey ve Toplum & $\begin{array}{l}\text { "Birlikte' adlı metinde kullanılan her sıfatı, anlamını } \\
\text { etkilediği her isimle birlikte bulunuz. Metindeki her sıfat, } \\
\text { önündeki isimle birlikte tahtaya yazınız. Öğretmeninizden, } \\
\text { yanlış tespitlerinizi düzeltmenizi isteyiniz. }\end{array}$ \\
\hline 6 & Birey ve Toplum & $\begin{array}{l}\text { Öğretmeninizden, sonraki metnin işlenişinin 'Yazma' } \\
\text { bölümünde kullanılmak üzere, 'işbölümünü gösteren resim ve } \\
\text { fotoğraflar' bularak bunları sinıfa getirmesini isteyiniz. } \\
\text { Öğretmeninize, yine 'Yazma' bölümünde kullanılmak üzere } \\
\text { sözsüz müzikler belirleyerek bunları bir CD ya da USB bellek } \\
\text { aracıllğıyla sınıfa getirmesini ve bir dizüstü bilgisayar ile } \\
\text { hoparlör temin etmesini de söyleyiniz. }\end{array}$ \\
\hline 6 & Çocuk Dünyası & $\begin{array}{l}\text { Kendi bölümünüzü okumaya beş dakika süreyle } \\
\text { hazırlanını. Öğretmeninizin okuma sırasını belirlemesinden } \\
\text { sonra kendi bölümünüzü koro halinde okuyunuz. En başarıl1 } \\
\text { olan grubu, sınıfla birlikte belirleyiniz ve ilan ediniz. }\end{array}$ \\
\hline
\end{tabular}




\begin{tabular}{ll}
\hline \multirow{2}{*}{ İletişim } & Sonraki metnin işlenişinin 'Yazma' bölümünde \\
gerçekleştirmek üzere öğretmeninizden ‘cep telefonları ve \\
insan' konulu bir konuşma hazırlığı yapmasını isteyiniz.
\end{tabular}

$6 \quad$ İletişim

Ailenizle birlikte yaşınıza uygun bir film izleyiniz. Filmde anlatılan olayı, filmin verdiği iletileri not ediniz ve bunları, sonraki derste arkadaşlarınızla paylaşınız.

\begin{tabular}{|c|c|c|}
\hline 6 & İletişim & $\begin{array}{l}\text { 'Pulsuz Dilekçe' adlı metinde kullanılan edatları bulunuz } \\
\text { ve bunları tahtaya yazınız. Öğretmeninizden, varsa yanlış } \\
\text { tespitlerinizi düzeltmesini isteyiniz. }\end{array}$ \\
\hline 6 & İletişim & $\begin{array}{l}\text { Yazdığınız metni grupça, dil-anlatım, yazım-noktalama ve } \\
\text { içerik bakımından değerlendiriniz ve bu değerlendirmeye } \\
\text { bağlı olarak gereken düzeltmeleri yapınız. Düzeltme } \\
\text { çalışmalarının tamamlanmasından sonra metni sınıfa } \\
\text { getirdiğiniz A4 ebadındaki kâğıtlara yazınız. }\end{array}$ \\
\hline 6 & Doğa ve Evren & $\begin{array}{l}\text {...̈̈ğretmeninizden, güvenilir olduğuna karar verilen } \\
\text { bütün internet adreslerini tahtaya yazmasını isteyiniz. }\end{array}$ \\
\hline 6 & Bilim ve Teknoloji & $\begin{array}{l}\text { Sonraki metnin işlenişinin 'Dinleme' bölümünde } \\
\text { kullanılmak üzere öğretmeninizden bir bilim insanının } \\
\text { herhangi bir konuda bilgi verdiği en az beş video bulmasını, } \\
\text { videoları bir USB bellek ya da CD'ye kaydetmesini rica } \\
\text { ediniz. Öğretmeninize, videoların izlenebilmesi için gerekli } \\
\text { hazırlığı yapmasını (dizüstü bilgisayar, hoparlör temin } \\
\text { edilmesi, varsa projeksiyon cihazının hazırlanması) da } \\
\text { söyleyiniz. }\end{array}$ \\
\hline 7 & Vatandaşlık & $\begin{array}{l}\text { Sınıf mevcudunuza göre gruplar oluşturunuz. Grupça } \\
\text { devlet yöneticileri ile vatandaşların görev ve sorumlulukları } \\
\text { konusunda çeşitli kaynaklardan araştırma yapını. Araştırma } \\
\text { sonucunda elde ettiğiniz bilgilerle bir sunum hazırlayınız... }\end{array}$ \\
\hline 8 & Sanat & $\begin{array}{l}\text { Geleneksel Türk el sanatları hakkında büyüklerinize } \\
\text { sorarak ya da çeşitli kaynaklardan yararlanarak araştırma } \\
\text { yapınız. }\end{array}$ \\
\hline
\end{tabular}

Ders kitabı öğrencilerin konulara ait bilgileri belli bir sırada ve amacına uygun şekilde öğrenmeleri adına dersin öğretim programında ifade edilen amaçlara uygun olarak hazırlanmış olan yazılı materyallerdir. Öğrencinin öğrenme ile ilgili deneyimlerinde sadece okulda değil; okul dışında da eşlik etmesi, öğretmenin öğretim ortamında gücünü daha iyi kullanması ve sistematik bilgiler sunmasına imkân veren araçlar olması nedeniyle doğru bir şekilde yapılandırılması ve dersin öğretimi, kazandırılmak istenen hedef davranışlar ile ilişkili bir biçimde, onun belirlediği ölçütler doğrultusunda hazırlanması gereken bir eğitsel ortamı ifade eder (Ünveren Kapanadze, 2018a). Böylesi bir işlevi olan ders kitapları, yapılandırmacı yaklaşım bağlamında bilişsel psikolojinin ortaya koyduğu kuramsal çerçeveyi ve öğrenme-öğretmeye dair önermelerini de şüphesiz barındıracaktır.

Çalışmanın kuramsal çerçevesini oluşturan Vygotsky'nin bilişsel kuramının temelindeki asıl unsurların çocuğun/öğrencinin bağımsız bir şekilde problem çözmesi olarak ifade edilen gerçek gelişim 
düzeyi ile bir yetişkin/rehberle iş birliği yaparak problemi çözme şeklinde belirtilen gizil gelişim düzeyi arasındaki fark olarak tanımını yaptığı yakınsal gelişim alanı; çalışmanın verilerinin edinildiği Türkçe ders kitaplarında (5-8) tespit edilen bir bilişsel olgu olmuştur. Her sınıf düzeyinde ve her ünitede yer almamış olsa da yakınsal gelişism alanını ifade eden yapılara Türkçe ders kitaplarında (5-8) yer verilmiştir.

Yakınsal gelişim alanının meydana gelmesi her şeyden evvel ortak bir kültürel evren içindeki etkileşim ve iletişime bağlıdır. Bu etkileşim formal ve informal ortamlar içerisinde de olabilir. Çalışmanın örneklemini oluşturan ders kitaplarından elde edilen verilerden bazıları incelendiğinde, çocuğun/öğrencinin yakınsal gelişim alanının oluşmasında bu sosyal iletişim ve etkileşime yer verildiği görülecektir. 5. Sınıf Ders Kitabı'nda yer alan Aileniz ya da çevrenizdeki yetişkinlerden çocukluklarında oynadıkları bir oyunu öğreniniz ile Çocukluk konulu bir şiir ezberleyiniz. Öğretmeninizin belirlediği bir zamanda şiirinizi vurgu, durak ve tonlamaya dikkat ederek fon müziği eşliğinde okuyunuz. Gerektiğinde ögretmeninizden örnek bir okuma isteyebilirsiniz ya da farklı kaynaklardan şiirin okunuşunu dinleyebilirsiniz ifadeleri bu bağlam içerisinde değerlendirilebilir.

Şüphe yok ki birtakım psikolojik işlemler, yaşanılan sosyal çevre ve onunla etkileşimle şekillenmektedir. Kişinin yaşadığı sosyal çevrenin bir dış kontrol mekanizması oluşturduğu bu anlamda açıktır. Gelişim ve öğretim arasındaki karmaşık ilişkiler unsuru da göz önünde bulundurulduğunda bu bağlam içerisinde öğrenmelerin salt formal yapılar içerisinde olmayacağı da öngörülebilir bir durumdur. Yetişkinlerin, çocukların bilişsel gelişimlerini istendik ve sistematik bir şekilde geliştirebilecekleri varsayımından yola çıkıldığında Geleneksel Türk el sanatları hakkında büyüklerinize sorarak ya da çeşitli kaynaklardan yararlanarak araştırma yapınız ile Ailenizle birlikte yaşınıza uygun bir film izleyiniz. Filmde anlatılan olayl, filmin verdiği iletileri not ediniz ve bunları, sonraki derste arkadaşlarınızla paylaşınız ifadeleri yine yakınsal gelişim alanının yetişkinlerle ilgili boyutunu ortaya koymak adına değerlendirilebilir.

Eğitim-öğretim ortamının birçok değişkeni bulunmaktadır. Bu değişkenlerden en önemlisi şüphe yok ki öğretmendir. Yapılandırmacı yaklaşımının temel unsurları içerisinde öğretmen; bilgiyi doğrudan sunan değil, bilgi edinmede ve onu yapılandırmada rehberlik eden kişidir. Daha önce de öğrencinin/ç̧ocuğun tek başına öğrenebileceği ya da var olan gelişim düzeyiyle, bir başkasının yardımıyla ulaşabileceği potansiyel gelişim düzeyi arasındaki fark, şeklinde ifade edilen yakınsal gelişim alanı olgusu düşünüldügünde 'Birlikte' adlı metinde kullanılan her sıfatı, anlamını etkilediği her isimle birlikte bulunuz. Metindeki her sifatl, önündeki isimle birlikte tahtaya yazını. Öğretmeninizden, yanlış tespitlerinizi düzeltmenizi isteyiniz gibi durum ve yönergeler yakınsal gelişim alanı içerisinde öğretmenin rolü bağlamında değerlendirilmelidir.

Yakınsal gelişim alanının Türkçe ders kitaplarında varlığını inceleyen bu araştırmada ders kitaplarının organizasyon şeması içerisinde yer alan hazırlık, sonraki derse hazırlık ve etkinlik yapıtaşları içerisinde Vygotsky'nin söz konusu kavramının bulunduğu, bu etkinlik ve yönergelerle bu alanın desteklendiği tespit edilmiştir. Yapılan incelemede ders kitaplarının her ünitesinde yakınsal gelişim alanı ile ilgili yapıların olmadığı ayrıca her sınıf düzeyinde de eşit ya da oranlı bir şekilde bulunmadığı da bulgulara yansımıştır. Bununla beraber Vygotsky'nin bilişsel gelişim kuramının diğer temel yapı taşları olan sosyal-kültürel model, iş birlikli öğrenme gibi unsurların baskın şekilde bulunduğu da tespit edilmiştir.

Yukarıdaki tabloda betimsel olarak verilen ifadeler incelendiğinde, söz konusu yapı ve yönergeler başta da ifade edildiği üzere çocuğun/öğrencinin bir yetişkin rehberliğinde başka bir deyişle sosyal çevrenin etkisiyle çalıştığında ortaya koyacağı alanı ifade etmektedir.

\subsection{Türkçe Öğretim Programına Dair Bulgular}

Eğitim- öğretim faaliyetlerinin amaçlı ve planlı olması gerekliliği nedeniyle eğitim kurumlarında düzenlenen etkinlikler önceden hazırlanan planlar, programlar aracılığıyla yürütülür. Resmî olarak hazırlanan bu programlar tüm eğitim-öğretim kurumlarında uygulanır. Eğitim programı, bir eğitim kurumunun yaygın ve örgün öğretiminde yer alan herkes için, millî eğitim ile programın uygulanacağ1 kurumların gelişmesine yönelik tüm eylemleri içine alır. Sadece dersler değil; çeşitli faaliyetler, özel 
gün kutlamaları, geziler, desteklemeler, rehberlik çalışmaları vb. işlevler ve sunulanlar hep programın belirlediği çerçeveye girer (Varış,1994).

Programlar ne, ne için, ne zaman, nasıl ve ne ile sorularının temelleri üzerine inşa edilirler. Başka bir ifadeyle bireylere neyin, nasıl öğretileceği, ne kadar ya da ne derece öğrenilip öğrenilmediğinin nasıl anlaşılacağı gibi sorulara verilecek cevaplar ortaya çıkınca da eğitim programının öğeleri olan hedef/kazanımlar, içerik, eğitim durumları ve sınama durumları belirlenmiş olur (Ünveren Kapanadze, 2018b).

Programların bu hususiyetleri bağlamında, işlerin başarılması sürecinde gerçekleştirilen zorlamalar en üst düzey bilişsel gelişime katk1 sağlar. Çocuğun/öğrencinin kendi başına başaramadığ 1 ancak başkalarının desteğiyle başarabildiği işleri yakınsal gelişim olarak niteleyen Vygotsky'nin; gelişimin çocuğun yakınsal gelişim alanında yer alan işlerin başarılmasıyla sağlanacağına (Baysen ve Silman, 2012) vurgu yaptığı göz önünde bulundurulduğunda, bu anlamda Türkçe Öğretim Programı'nın Öğrenme Yaklaşımı içerisinde yer alan: Öğrencilerin öğrenme ögretme sürecine aktif katılımı sağlanmalı ve ögrenciler kendi öğrenmelerinin sorumluluğunu almaları konusunda teşvik edilmelidir. Öğrencilerin ögrendiklerini içinde yaşadıklart sosyokültürel ve çevresel durumlarla ilişkilendirmelerine imkân sağlayan, aktif olarak katılabilecekleri etkinlik ve çalışmalara yer verilmelidir. Bu tarz etkinlik ve çalışmalar öğrenmeyi daha anlaml ve kalıcı kılmakla birlikte öğrenmeye karş̧ olumlu tutum geliştirmelerine katkı sağlayacaktır (MEB, 2018) ifadeleri yakınsal gelişim alanı içerisinde değerlendirilmelidir. Çünkü öğrencilerin kendi öğrenmeleri konusunda nasıl bir yol izleyecekleri, kendi başlarına neleri başarabilecekleri konusunda bir rehbere başka bir ifadeyle öğretmene ihtiyaç vardır. $\mathrm{Bu}$ durumda öğrenci için asıl beceri, öğretmen gibi daha ileri seviyede bulunan bir kişinin yardımını alarak ulaşabileceği en üst seviyedeki potansiyel gelişimi sağlamış olmasıdır.

\section{Sonuc}

İnsanlar ana dillerinde düşünüp üretirler. Ana dili dersleri hiçbir ulusun vazgeçemeyeceği, kaldıramayacağı bir ders türü de olmakla birlikte, bu dersin sürekli olarak daha iyi şekilde nasıl yapılandırılabileceği hususu gündemde olmalıdır. Ana dilinin bilişsel gelişimdeki yeri ve önemi oldukça açıktır. Bu bağlamda bu derslerin çocukların bilişsel gelişimini destekleyecek şekilde kurgulanması, uygulanması ve ders kitapları başta olmak üzere materyallerinin de bu yönde hazırlanması aynı derecede öneme sahiptir.

Vygotsky'e göre çocuklar çevresindeki kişiler aracılığıyla öğrenmeye başladıklarından öğrendikleri bilgi, beceri, düşünce ve tutumlarının en önemli kaynağı sosyal çevre olarak ortaya çıkmaktadır. Aynı şekilde dil öğrenme sürecini de çocuklar/öğrenciler başkalarıyla etkileşerek ve zihinsel becerilerini geliştirerek gerçekleştirirler. Dil ve öğrenmenin ayrılmaz bir şekilde birbirine bağlı olduğu da göz önünde bulundurulduğunda öğrenmenin dili gerektirdiği dilin de öğrenmeyi etkilediği söylenmelidir. $\mathrm{Bu}$ yüzden, öğrenme sürecinde dil ve zihinsel becerileri geliştirme bir arada düşünülmeli ve ele alınmalıdır (Güneş, 2007a; 2007b). Öğrenmenin en etkili aracı dildir. Aynı zamanda dil öğrenme yoluyla bilişsel süreçleri yönlendirmekte öğrenme alanının sınırlarını çizmektedir. Dil kullanım becerileriyle öğrenme arasında doğrudan bir ilişki vardır (Onan, 2012). Dolayısıyla da, bilişsel kuramların göz ardı edildiği ya da vurgulanmadığı dil derslerinin hem dil gelişimini hem zihinsel gelişimi hem de öğrencilerin genel olarak öğrenme süreçlerini olumsuz yönde etkileyeceği düşünülmektedir.

Alman bilim adamı Wilhelm Von Humbolt'a göre dil, içinde bulunduğu toplumdan ve o toplumun üyelerinden bağımsız, yalıtılmış bir kavram değildir. Dil bir milletin birikimini, deneyimlerini ve karakterini yansıtır. O bir yaşantılar toplamı, düşünceler zinciri ve bir dünya formudur (1988). Bu bağlamda, ana dil öğretiminin gerçekleştiği derslerin bu ilke göz önünde bulundurularak yapılması dilin doğasına uygun olacağ 1 gibi, öğrencilerin diğer öğrenmelerini ve bilişsel gelişimlerini de etkileyecektir. Bilişsel gelişim adına oldukça önemli olan Türkçe derslerinde ders kitaplarının bilişsel gelişime uygun bir şekilde ve onu destekleyecek yönde hazırlanmış olması yeterli değildir; onları etkili bir şekilde kullanacak öğretmenlere de ihtiyaç vardır (Yapıcı, 2004).

Ders kitapları ve öğretim programını incelediğimiz Ortaokul (5-8) yaş grubunun, sosyal olaylar ve deneyimler ile aile yaşamına ait meseleler ile bilgi sahibi oldukları ve bu konularla ilgilenmeye başladıkları görülür. Bu bağlamda dilsel gelişimleri adına, onlara, sosyal olaylar hakkında fikirlerini 
alma, sorularını cevaplama, izledikleri ve okudukları üzerindeki kültürel farklılıklar hakkında konuma gibi etkinlikler önerilir. Ayrıca, bu dönemdeki çocukların grup içerisinde duygularının tartışılmasının kendilerini daha iyi anlamalarına yardımcı olacağı belirtilir. Bu nedenle de sosyal ortamda grup içi tartışmalarla kendilerini ifade edecekleri etkinlik ve ortamlar önerilir (Ayrancı, 2018). Ayrıca, Türkçenin ana dili olarak öğretiminde ders kitaplarında yapılandırılan öğrenme öğretme sürecini bilgi işleme modeli çerçevesinde analiz ettiği çalışmasında Onan (2012), bilgi işleme modelini oluşturan zihinsel yapılar ve bilişsel süreçlerin öğrenme ortamında mutlak suretle öğretmenler tarafindan göz önünde bulundurulması gerektiği sonucuna ulaşmıştır. Bu noktada, bu çalışmaya konu olan sosyal öğrenmenin ve yapılandırmanın, özellikle de ele aldığımız hedef kitlede bir hayli önem kazandığı başka çalışmalarda da görülmektedir.

Türkçe dersinin öğrenme öğretme süreci hem birbirini tamamlayıcı nitelikte hem de farklı öğrenme etkinliklerini merkeze alan yapılardan oluşmaktadır. Bütün bir öğrenme-öğretme sürecinde temel dil becerileri olarak ifade edilen dinleme, konuşma, yazma ve okuma alanlarına yönelik programda belirtilen kazanımlar doğrultusundaki öğrenme etkinlikleriyle birlikte öğrencilerin üst düzey düşünme becerilerinin geliştirilmesi ve toplumsal beceriler edinmesiyle ilgili olan öğrenme etkinlikleri de yer almakta ve düzenlenmektedir. Öğrencilerin bütün yönlerden kendilerini gerçekleştireceği zengin öğrenme ortamlarının oluşturulması bu anlamda değerli ve önemlidir. Yalnızca sınıf ortamı ve ders kitaplarının sunduğu öğrenmelerin değil; bireysel farklılıklar ve farklı öğrenme stillerinin de merkeze alındığı öğrenme ortamlarının öğrenen bireylere sunulması gerekmektedir.

Vygotsky'e göre yetişkin ve çocukların işbirliği içinde çeşitli etkinlikler yapmaları, öğrenmeyi kolaylaştırmanın yanı sıra dil ve zihinsel becerilerin gelişimini de desteklemektedir. Dolayısıyla da özellikle de dil derslerinde işbirlikli öğrenmeye ağırlık verilmelidir. Bu süreçte iki düzeye dikkat edilmelidir; öğrencinin mevcut gelişim düzeyi ile birinin rehberliğinde bir işi yapabilme düzeyidir. $\mathrm{Bu}$ ikisi arasındaki fark öğrencinin gelişmeye açık alanını belirtmektedir (Lemire, 2005; akt. Güneş, 2011). $\mathrm{Bu}$ gelişmeye açık alan bir uzman, öğretmen, akran, anne-baba yardımıyla geliştirilirse öğrenci daha sonra etkinlikleri kendi başına yapabilir. İşte bu noktada işbirlikli öğrenme yöntemleri devreye sokulmalı ve bu tarz etkinliklerde öğrencilerin düşünme, anlama ve problem çözme süreçleri denetlenmelidir. Ayrıca bu uygulamaların öğrencilerin dil, anlama, öğrenme ve zihinde yapılandırma süreçlerini geliştirmeye, onları bağımsız düşünen, sorun çözen ve üreten bireyler haline getirmeye yönelik olmasına dikkat edilmelidir. Bu süreçte sosyal-zihinsel etkileşimler yoluyla öğrenilen bilgiler zihinsel gelişimi hızlandırmakta ve bireyin toplumda başarılı bir yetişkin olmasını getirmektedir (Barnier, 2005; akt. Güneş, 2011). Bu bağlamda hem ders kitaplarının hem de öğretim programlarının kurgulanma aşamasında bu süreçlere önem verilmesinin, bilinçli bir şekilde bu durumun üzerine gidilmesinin, bu tarz etkinlikler ve bunlara dair yönergelerin sayıca da arttırılmasının çok yönlü kazanımları doğuracağı düşünülmektedir.

Bununla birlikte, çocuğun yakınsal gelişim alanının genişliği, yardımla ve eğitimle daha üst bir düzeye erişebilir olduğundan, aynı zamanda da onun yeni gelişim düzeylerine erişmesine öncülük edeceğinden, eğitimin geçmişe değil geleceğe dönük olmas1 ve eğitim eşiğinin her zaman çocuğun gelişim seviyesinin üzerinde tutulması büyük önem arz etmektedir (Erneder, 2009). Türkçe öğretim programının ve ders kitaplarının da bu önemli ilke göz önünde bulundurularak yeniden gözden geçirilmesi gerektiği düşünülmektedir.

Vygotsky bu gelişime açık yakınsal gelişim alanını ifade ederken bir silindir benzetmesi yaparak bu olguyu somutlaştırma yoluna gider. Ona göre bireyin gelişimi adeta sonu olmayan bir silindir gibidir. $\mathrm{Bu}$ silindirin üzerinde yukarıya doğru kayan yakınsal gelişim alanı vardır ve bunun temelini, zeminini de bir başkasından yardım almadan çözebileceği problemler oluşturur. Kişinin problemlerle baş etme ve problemi çözme becerileri geliştikçe silindir yukarı doğru çıkar. Silindirin tepesinde yani tavanında ise kendi başına çözemeyeceği problemler vardır. Bu iki kutup arasında ise bireyin yardım alarak çözebileceği problemler bulunmaktadır. Karmaşık zihinsel süreçlerin sosyal etkileşimlerle başladığı ve öğrenci/çocuk geliştikçe sosyal durumlarda kullandığı bu süreçleri zamanla içselleştirdiği ve daha sonra bağımsız bir şekilde kullandığ önermesi üzerine de inşa edilmiş olan Vygotsky'nin bilişsel gelişim kuramının önemli bir ayağı olan yakınsal gelişim alanı; ileri veya daha başarılı kişilerin yardımının çocukların zor hedeflere ulaşmasını sağladığı düşüncesi üzerine kurulur. Bu anlamda yakınsal gelişim alanının Türkçe öğretimindeki varlığı ve Türkçe öğretimine ne şekilde yansıdığının araştırıldığı bu 
çalışmada elde edilen veriler ışığında; gerek öğretim programının yaklaşımında gerekse öğretim materyallerinde yakınsal gelişim alanını destekleyen, bu olguyla ilgili olan yapıların varlığının olduğu görülmüştür.

\section{5. Öneriler}

$>$ Öğrencilerin iş birliği içinde çalışmaları ve birlikte başarma duygusunu yaşayacakları durumlar teşvik edilmelidir.

$>$ Kültürel değerler ve kavramlara eğitim sürecinde yer verilmeli hatta bu değer ve kavramlar öğrenme-öğretme ortamlarının temel nesnesi haline getirilmelidir.

> Öğretmenler öğrenme ortamlarında kontrollü bir biçimde öğrencilerin özerk bir şekilde çalışmalarına alan açmalıdır.

$>$ Değerlendirme yapılırken sadece bireysel değil; grupla da değerlendirme yapılmalıdır.

> Grupla yapılabilecek etkinliklere ağırlık verilmeli ve öğrencilerin kendilerini değerlendirmelerine olanak sağlayacak durumlara alan açılmalıdır.

> Öğrenme ortamının sadece okul/sınıf olmaktan çıkarılarak çevre ile etkileşimi sağlayacak öğrenme ortamları tesis edilmelidir. 


\section{Kaynakça}

Ayrancı, B. B. (2018). 0-12 Yaş Dil Gelişimi Uygulamaları ve Yapılması Gerekenler. Kırıkkale Üniversitesi Sosyal Bilimler Dergisi, 8 (1), 13-34.

Balaban, N. (1995). Seeing the Child, Knowing the Person." Ayers, W. (Ed.), To Become a Teacher içinde (s. 49-57). New York: Teachers College Press.

Barnier, G. (2005). L'approche socio-constructive des apprentissages scolaires, Psychologie de l'éducation, Thème 2. IUFM d'aix-Marseille.

Bayhan, P. ve Artan İ. (2007). Çocuk Gelişimi ve Eğitimi. İstanbul: Morpa Kültür Yayınları.

Baysen, E. ve Silman, F. (2012). Yapılandırmacı Yaklaşım, Öğrenme ve Öğretme Kuramlar, Yaklaşımlar, Modeller (Ed. Zeki Kaya). Ankara: PegemA Yayınları 197-225.

Benson, B. (1997). Scaffolding (Coming to Terms). English Journal, 86(7), 126-127.

Berk, L. (2002). Child Development. (5. Ed). Boston: Allyn and Bacon.

Crandall, J., \& Kaufman, D. (Eds.) (2002). Content Based Instruction in Higher Education Settings, TESOL Inc, 29-45.

Daniels, H. (2001) Vygotsky and Pedagogy. NY: Routledge/Falmer.

Driscoll, M. P. (2012). Öğretim Süreçleri ve Öğrenme Psikolojisi (Çev. Ömer F. Tutkun ve Seçil Okay Evrim), Ankara: Anı yayıncılık.

Duman, B. (2004). Öğrenme Öğretme Kuramları ve Süreç Temelli Öğrenme, Ankara. Anı Yayıncılık.

Eggen, P \& Kauchak, D. (1999). Educational Psychology. Prentice-Hall: New Jersey

Erdener, E. (2009). Vygotsky’nin Düşünce ve Dil Gelişimi Üzerine Görüşleri: Piaget'e Eleştirel Bir Bakış. Türk Eğitim Bilimleri Dergisi, 7(1), 85-103

Güneş, F. (2007a). Ses Temelli Cümle Yöntemi ve Zihinsel Yapılandırma, Ankara: Nobel Yayınları.

Güneş, F. (2007b). Türkçe Öğretimi ve Zihinsel Yapılandırma, Ankara: Nobel Yayınları.

Güneş, F. (2011). Dil Öğretim Yaklaşımları ve Türkçe Öğretimindeki Uygulamalar. Mustafa Kemal Üniversitesi Sosyal Bilimler Enstitüsü Dergisi, 8(15), 123-148.

Hamamcı, Z. ve Hamamcı, E. (2015). Çocuk Gelişimi Kuramları ve Dil Öğretmenleri İçin Yansımaları, Ĕ̈itim ve Ögretim Araştırmaları, 4 (1), 125-134.

Hammond, J. (Ed.) (2002). Scaffolding Teaching and Learning in Language and Literacy Education. Newtown, Australia: PETA

Haykır, H., Kaplan, H., Kıryar, A., Tarakçı, R. ve Üstün, E. (2018). Ortaokul ve İmam Hatip Ortaokulu 5. Sinıf Türkçe Ders Kitabı, Ankara: Devlet Kitapları, Özgün Matbaacılık.

Humboldt, W. (1988). On Language. Peter Heath (Çev). Cambridge: Cambridge University Press.

Karasar, N. (2007). Bilimsel Araştırma Yöntemi. Ankara: Nobel Yayın Dağıtım.

Kaya, A. (Ed.) (2010). Eğitim Psikolojisi. Ankara: Pegem Yayınları.

Kaya, B. (2018). Ortaokul ve İmam Hatip Ortaokulu 7. Sinıf Türkçe Ders Kitabı, Ankara: Ders Destek Yayınlar1.

Krause, K., Bochner, S. \& Duchesne, S. (2003). Educational Psychology for Learning and Teaching. Australia: Thomson

Jacobs, G. (2001). Providing the Scaffold: A Model for Early Childhood/Primary Teacher Preparation. Early Childhood Education Journal, 29 (20),125-130. 
Lemire, G. (2005). Fondements théoriques 1 Assises constructiviste, socioconstructiviste et cognitiviste, Université Laval, http://www. cours. fse. ulaval. ca/frn- 19972/osp_presentation/ep_p_11. Html

McDevitt, T.M. \& Ormrod, J.E. (2002). Child Development and Education. Upper Saddle River, NJ: Merrill Prentice Hall.

MEB Komisyon (2018).Türkçe Dersi Öğretim Programı (1-8), Ankara.

Mete, G., Karaaslan, M., Kaya, Y., Ozan, Ş., Özdemir, D. (2018). Ortaokul ve Imam Hatip Ortaokulu 8. Sinıf Türkçe Ders Kitabı, Ankara: Devlet Kitapları, Saray Matbaacılık.

Miles, M. B. \& Huberman A. M. (1994). An expanded sourcebook: Qualitative data analysis. CA: Sage Publications.

Onan, B. (2012). Türkçenin Ana Dili Olarak Öğretiminde Bilgi İşleme Süreci. Mersin Üniversitesi Eğitim Fakültesi Dergisi, 8 (1), .96-113.

Ormrod, J. E. (2018). Öğrenme Psikolojisi, (Çev. Ed. Mustafa Baloğlu), Ankara: Nobel yayınc1lık.

Rasmussen, J (2001) The Importance of Communication in Teaching: a Systems-Theory Approach to the Scaffolding Metaphor. Curriculum Studies, 33 (5), 569-582.

Schunk, H. D. (2014) Eğitimsel Bir Bakışla Öğrenme Teorileri (Çev. Ed. Şahin, Muzaffer). Ankara: Nobel Yayınları.

Stone, A. (1998). The Metaphor of Scaffolding: Its Utility for the Field of Learning Disabilities. Journal of Learning Disabilities, 3 (4), 344-364.

Şahin, C. (Ed.), (2016). Eğitim Psikolojisi, Gelişim-Öğrenme-Öğretim. Ankara: Nobel Yayınc1lık.

Şekerci, Y. (2018). Ortaokul ve İmam Hatip Ortaokulu 6. Sinıf Türkçe Ders Kitabı, İstanbul: Eksen Yayincilik.

Ünveren Kapanadze, D. (2018a). Dil ve Kültür Aktarımında İşlevsel Bir Araç Olarak Ders Kitapları: Türkçe Ders Kitapları Örneği, Turkish Studies, 13 (27), 1575-1592.

Ünveren Kapanadze, D. (2018b). Toplumsal Bellek Bağlamında Kültür, Dil ve Öğretimi, Eğitim Bilimleri. (Ed. Oğuz Kutlu). Ankara: Akademisyen Kitabevi, 299-322.

Varış, F. (1994). Eğitimde Program Geliştirme, Teori ve Teknikler. Ankara: Alkım Kitapçılık Yayinc1lik.

Winne, P. H. \& Hadwin, A.F (2001). CoNoteS2: A software tool for promoting self-regulation. Educational Research and Evaluation 7(2/3), 313-334.

Wood, D., Bruner, J.S., \& Ross, G. (1976). The role of tutoring in problem solving. Journal of Psychology and Psychiatry. 17. 89-100

Vygotsky, L. (1978). Mind in Society. Cambridge Mass: Harvard University Press.

Vygostky, L. S. (1998). Düşünce ve Dil. İstanbul: Toplumsal Dönüşüm Yayınları.

Yapıcı, M. (2004). İlköğretim dilbilgisi konularının çocuğun bilişsel düzeyine uygunluğu, İlköğretimOnline, 3(2), 35-41.

Yıldırım, A. ve Şimşek, H. (2015) Sosyal Bilimlerde Nitel araştırma Yöntemleri, Ankara: Seçkin Yayıncilik.

Yıldırım, Y. (2016). Eğitim Sosyolojisi Perspektifi ile Piaget ve Vygotsky'nin Bilişsel Gelişim Kuramları Üzerine Sosyolojik Bir Analiz Denemesi. Bartın Üniversitesi Ë̆itim Fakültesi Dergisi, 5 (2), $617-628$.

Yurdakul, B. (2005) Eğitimde Yeni Yönelimler, (Ed. Özcan Demirel) PegemA Yayıncılık. Ankara, 3965. 


\section{Extended Abstract}

The main proposition of socio-cultural constructivism, developed around Vygotsky's ideas and views is that social interaction is an important part of cognitive development. In this approach, the necessity of social environment which will provide a rich experience in the learning process, the presence of experienced peers and teachers have an important place in the development of cognitive functions. In this context, the main aim of the study is to evaluate Turkish language teaching in terms of zone of proximal development, which is one of the important concepts Vygotsky's Cognitive Development Theory and to investigate how this concept was reflected in Turkish teaching. While doing analysis, approaches and strategies around Vygotsky's views and other cognitive development theories were taken into consideration.

In the study, document analysis, a qualitative research method, was used and secondary school Turkish textbooks $\left(5-8^{\text {th }}\right)$ and Turkish curriculum were analyzed. Document analysis is a systematic review of the analysis of written materials in the pursuit of information on the topic to be investigated. The data collection instruments in the study are composed of Turkish language teaching curriculum and textbooks $\left(5-8^{\text {th }}\right.$ grade). The sections in the books which are; 'preparation for the coming section, listening, reading, speaking, writing activities, preparation for next session, assessment questions' and 
'the instructions' related to these sections in the Turkish textbooks were examined. In the validity and reliability of the study, a detailed literature review were done and structures related to cognitive development and zone of proximal development theory of Vygotsky were identified in the Turkish textbooks $\left(5-8^{\text {th }}\right)$; after that the findings obtained from the documents examined were evaluated for reliability and validity together with two Turkish teachers and two experts in the area of learning and developmental psychology. The findings were compared with each other and re-classified as consensus and disaggregation formula of Miles and Huberman (1994). Thus, the reliability of the research was calculated as $90 \%$. Data were evaluated by descriptive analysis and presented on tables.

In this study through which the existence of opportunities which give way to the zone of proximal development in Turkish textbooks was examined, it was found that that this concept of Vygotsky was given place in the sections of 'preparation, preparation for next session and activities', and this area was supported through activities which were suggested and the instructions which were given regarding the activies. The findings also showed that there are no structures related to the zone of proximal development in each unit of the textbooks and they were not equally or proportionally distributed in each grade level. In addition, other main building blocks of Vygotsky's cognitive development theory such as social-cultural model and cooperative learning were predominantly identified in the Turkish books examined and in Turkish language teaching program.

In the context of the characteristics of teaching programs, the challenges in the process of achieving a task and learning, contribute to the highest level of cognitive development. Vygotsky described the works that the child / student could not achieve on his own but could accomplish with the support of others, as proximal development and emphasized the fact that development could be made possible by the achievement of the works in the zone of proximal development of the child. Taking these into consideration, the statements within 'the Learning Approach of the Turkish Curriculum/teaching program': Active participation of students in the learning teaching process should be ensured and students should be encouraged to take responsibility for their own learning. Activities and studies that enable students to associate with the sociocultural and environmental situations in which they live should be included. Such events and studies not only will make learning more meaningful and permanent, but will also contribute to the development of positive attitudes towards learning (MEB, 2018) could be evaluated in the framework of the zone of proximal development; because students need a mentor/ a coach in other words a teacher, to decide a way or method to follow in order to learn effectively and achieve learning goals and outcomes and in order to predict what they can accomplish by their own. In this case, the main skill for the student is that they have achieved the highest level of potential development by getting help from a more advanced person like a teacher.

In the light of the findings of the research, it has been concluded that there are structures related to the zone of proximal development and that support it, in the approach of teaching program and in the teaching materials which were reviewed and analyzed. 